\title{
Accumulation of total mercury and methylmercury in rice plants collected from different mining areas in China
}

\author{
Mei Meng a , Bing Li ${ }^{b}$, Jun-juan Shao a, Thanh Wang a , Bin He a , Jian-bo Shi ${ }^{\text {a, *, }}$ \\ Zhi-hong Ye ${ }^{\mathrm{c}}$, Gui-bin Jiang ${ }^{\mathrm{a}}$ \\ a State Key Laboratory of Environmental Chemistry and Ecotoxicology, Research Center for Eco-Environmental Sciences, Chinese Academy of Sciences, \\ Beijing 100085, China \\ ${ }^{\mathrm{b}}$ Ecological Civilization Construction Committee of Guiyang, Guiyang Research Academy of Environmental Sciences, Guiyang 550002, China \\ c State Key Laboratory for Bio-control and Guangdong Key Laboratory of Plant Resources, School of Life Sciences, Sun Yat-sen University, \\ Guangzhou 510006, China
}

\section{A R T I C L E I N F O}

\section{Article history:}

Received 24 February 2013

Received in revised form

2 August 2013

Accepted 9 August 2013

\section{Keywords:}

Total mercury

Methylmercury

Water soluble $\mathrm{Hg}$

Rice plants

Accumulation

\begin{abstract}
A B S T R A C T
A total of 155 rice plants were collected from ten mining areas in three provinces of China (Hunan, Guizhou and Guangdong), where most of mercury (Hg) mining takes place in China. During the harvest season, whole rice plants were sampled and divided into root, stalk \& leaf, husk and seed (brown rice), together with soil from root zone. Although the degree of $\mathrm{Hg}$ contamination varied significantly among different mining areas, rice seed showed the highest ability for methylmercury (MeHg) accumulation. Both concentrations of total mercury $(\mathrm{THg})$ and $\mathrm{MeHg}$ in rice plants were significantly correlated with $\mathrm{Hg}$ levels in soil, indicating soil is still an important source for both inorganic mercury ( $\mathrm{IHg}$ ) and $\mathrm{MeHg}$ in rice plants. The obvious discrepancy between the distribution patterns of $\mathrm{THg}$ and $\mathrm{MeHg}$ reflected different pathways of $\mathrm{IHg}$ and $\mathrm{MeHg}$ accumulation. Water soluble $\mathrm{Hg}$ may play more important role in $\mathrm{MeHg}$ accumulation in rice plants.
\end{abstract}

(c) 2013 Elsevier Ltd. All rights reserved.

\section{Introduction}

As a global pollutant, mercury ( $\mathrm{Hg}$ ) exists in various environmental media and transforms among a variety of species in nature. The toxicity of $\mathrm{Hg}$ is closely related to its chemical forms (Clarkson, 1998). As the most toxic Hg compound, methylmercury (MeHg) can be considerably accumulated in the aquatic food web, leading to fish at higher trophic levels with $10^{6}$ times higher Hg concentrations than ambient water (WHO, 1990; Stein et al., 1996; USEPA, 1997a). Seafood consumption is usually considered to be the primary route of human $\mathrm{MeHg}$ exposure (Clarkson, 1993). Studies have found that MeHg levels in human hair were positively correlated with fish consumption (Holsbeek et al., 1996; Al-Majed and Preston, 2000; Santos et al., 2002). However, recent studies in Guizhou province of China showed that consumption of rice grown at $\mathrm{Hg}$ mining areas was the main $\mathrm{MeHg}$ exposure pathway to local residents (Feng et al., 2008; Zhang et al., 2010a). Generally, total $\mathrm{Hg}(\mathrm{THg})$ levels in most foodstuffs are below the maximum permissible limit in China of $20 \mu \mathrm{g} \mathrm{kg}{ }^{-1} \mathrm{~d}$.w. for crops (GB 2762-

\footnotetext{
* Corresponding author.

E-mail address: jbshi@rcees.ac.cn (J.-b. Shi).
}

2005; Meng et al., 2011). But the study in Wanshan found that $\mathrm{THg}$ levels in rice could reach up to $569 \mu \mathrm{g} \mathrm{kg}$, of which $145 \mu \mathrm{g} \mathrm{kg}^{-1}$ occurred in MeHg form (Horvat et al., 2003). Rice serves as the staple food for over half the world's population (FAO, 2006), and therefore intake of contaminated rice could result in a potential health threat to humans.

Significant $\mathrm{MeHg}$ accumulation in rice has currently drawn increased international attention. Initial reports mostly focused on the determination of $\mathrm{Hg}$ levels in rice and the assessment of human exposure risk through rice intake. Elevated $\mathrm{MeHg}$ concentrations were reported in rice collected from Wuchuan, with the results revealing that air inhalation was the main inorganic $\mathrm{Hg}(\mathrm{IHg})$ exposure route, while rice intake was the main $\mathrm{MeHg}$ exposure route (Qiu et al., 2006; Li et al., 2008a). Later studies found that $\mathrm{MeHg}$ in rice in Wanshan was about 2-3 orders of magnitude higher than that in the edible portion of other local crop plants, implying that the accumulation of $\mathrm{MeHg}$ in rice was high (Qiu et al., 2008). Some other $\mathrm{Hg}$ mining areas in Guizhou province have also been investigated, such as Qingzhen (Horvat et al., 2003; Søvik et al., 2011), Lanmuchang (Wang et al., 2005), Tongren (Li et al., 2011) and Danzhai (Feng and Qiu, 2008), but to a less extent compared to Wanshan and Wuchuan. Although large-scale $\mathrm{Hg}$ 
mining activities in these mines have been officially ceased, smallscale and artisanal $\mathrm{Hg}$ or gold smelting activities have revived since a few years ago due to the increase of $\mathrm{Hg}$ price in the Chinese market (Feng et al., 2008). To date, few studies have been conducted on rice plants in other $\mathrm{Hg}$ mining provinces in China other than Guizhou province. The possible pathways of $\mathrm{MeHg}$ accumulation have been recently discussed in several publications. On average, the bioaccumulation factors of $\mathrm{MeHg}$ in rice grain could be over 800 times higher than those of IHg (Zhang et al., 2010b). Most of MeHg are firstly accumulated in the leaf and stalk parts and then transferred to seed during the ripening period (Meng et al., 2010, 2011). MeHg was also found to be mainly enriched in the endosperm whereas IHg was mostly located in the rice bran layer (Rothenberg et al., 2011). However, investigations on MeHg accumulation mechanisms in rice plants are still quite limited, and the dynamic processes of $\mathrm{MeHg}$ absorption, transformation and translocation remains largely unknown.

As known, $\mathrm{Hg}$ in soil occurs in various forms that can be bound to different matrix phases and these matrix phases vary upon mobility, bioavailability and potential toxicity (Issaro et al., 2009). Therefore, THg has been regarded as a poor indicator for the toxicological and environmental hazards of $\mathrm{Hg}$ contamination in soil. Normally, water soluble $\mathrm{Hg}(\mathrm{Hg}-\mathrm{w})$ is highly soluble, easily available to biota, and might serve as a main substrate for the methylation of IHg (Wallschlager et al., 1998; Boszke et al., 2006; Covelli et al., 2009). Studies in Wanshan have revealed a serious Hg contamination in local soil, with $\mathrm{THg}$ levels reaching up to $130,000 \mu \mathrm{g} \mathrm{kg}^{-1}$ (Lin et al., 2010). Since paddy fields are shallowly flooded during the rice growing season, $\mathrm{Hg}-\mathrm{w}$ may play an important role in methylation and accumulation of $\mathrm{Hg}$ in paddy fields. Unfortunately, this has been ignored in most previous studies.

In order to better understand the potential pathways of $\mathrm{IHg}$ and $\mathrm{MeHg}$ accumulation in rice plants, we emphasized our study on the following two aspects: (1) water soluble $\mathrm{Hg}(\mathrm{Hg}-\mathrm{w})$ in soil from the root zone was measured to explain the bioavailability and accumulation process of $\mathrm{Hg}$; (2) sampling areas were expanded to three provinces to verify the variation and consistency of $\mathrm{THg}$ and $\mathrm{MeHg}$ accumulation. The distribution patterns, possible sources and accumulation pathways of $\mathrm{THg}$ and $\mathrm{MeHg}$ in rice plants were discussed in detail. The results from this study could provide further information for better understanding the accumulation mechanism of $\mathrm{Hg}$ into rice plants.

\section{Materials and methods}

\subsection{Sampling sites description}

China is rich in $\mathrm{Hg}$ reserve, ranking the third in the world (Feng et al., 2008). Guizhou, Hunan and Guangdong provinces are three of the most important $\mathrm{Hg}$ producing areas in China. Moreover, rice is the major crop in these provinces and serves as staple food. In this work, ten typical mining sites were selected for sampling, among them five sites in Guizhou, including Danzhai (DZ), Lanmuchang (LMC), Tongren (TR), Wanshan Sikeng (WS) and Wanshan Wukeng (WS5), four sites in Hunan, including Dongping in Baojing (BJ) county, Chatian Chanshula (CSL), Chatian Jijian (JJ) and Niudouping (NDP) in Fenghuang county (with these three close to each other), and one Hg-contaminated mining site in Guangdong, that is, Fankou (FK) $\mathrm{Pb} / \mathrm{Zn}$ mining site. Fig. 1 shows the map of the study regions.

Guizhou province is located at the center of the circum-Pacific mercuriferous belt (Gustin et al., 1999; Qiu et al., 2006). The total cinnabar deposit in this province represents approximately $70 \%$ of the total in China (Qu, 2004). Hg mining activities in Guizhou have introduced large amounts of uncontrolled gangues and mine tailings. As a result, crops grown at these $\mathrm{Hg}$ mining areas contained elevated $\mathrm{Hg}$ (Feng et al., 2008a; Qiu et al., 2008). Wanshan was once the largest conglomeration of $\mathrm{Hg}$ mines and refining plants in China (Lin et al., 2010). Several studies have reported rather high concentrations of $\mathrm{Hg}$ in different environmental media of this area (Horvat et al., 2003; Qiu et al., 2005; Lin et al., 2010). DZ, LMC and TR are all large Hg mines in Guizhou, but few studies have been reported on $\mathrm{Hg}$ accumulation in rice plants grown in these areas. Western Hunan province also situates an $\mathrm{Hg}$ belt, ranking the fifth largest in China. Chatian Hg mining deposit (CMD) is the most important mine in this $\mathrm{Hg}$ belt, with a long history of $\mathrm{Hg}$ mining. Previous studies have reported heavy $\mathrm{Hg}$ pollution in $\mathrm{Pb} / \mathrm{Zn}$ mine area located in adjacent town in Fenghuang County (Li et al., 2007). Guangdong province is another important $\mathrm{Hg}$ producing area. Fankou $\mathrm{Pb} / \mathrm{Zn}$ mine in Shaoguan city is the largest geological reserved mining area in Asia. As $\mathrm{Hg}$ is a major associated element in zinc ores, zinc smelting has led to serious $\mathrm{Hg}$ pollution (Li et al., 2008b). Studies showed that $\mathrm{Hg}$ levels in soils and vegetables of this mine exceeded the Chinese National Standard (GB 15618-1995; GB 2762-2005) by 32.3\% and 9.4\%, respectively (Wang et al., 2012).

\subsection{Sample collection and pretreatment}

During rice harvest season in 2010, a total of 155 rice plants were collected from the ten mining areas. Whole rice plant together with soil samples from the root zone $(10-20 \mathrm{~cm}$ in depth) were collected from the first four sites, DZ $(n=11)$, WS $(n=21)$, LMC $(n=15)$ and FK $(n=18)$. Parts of rice plant (seed and husk, $n=15)$ as well as corresponding soil samples $(n=15)$ from the root zone were collected from each of the other six sites, BJ, CSL, JJ, NDP, TR and WS5. In all sampling sites, each sample was

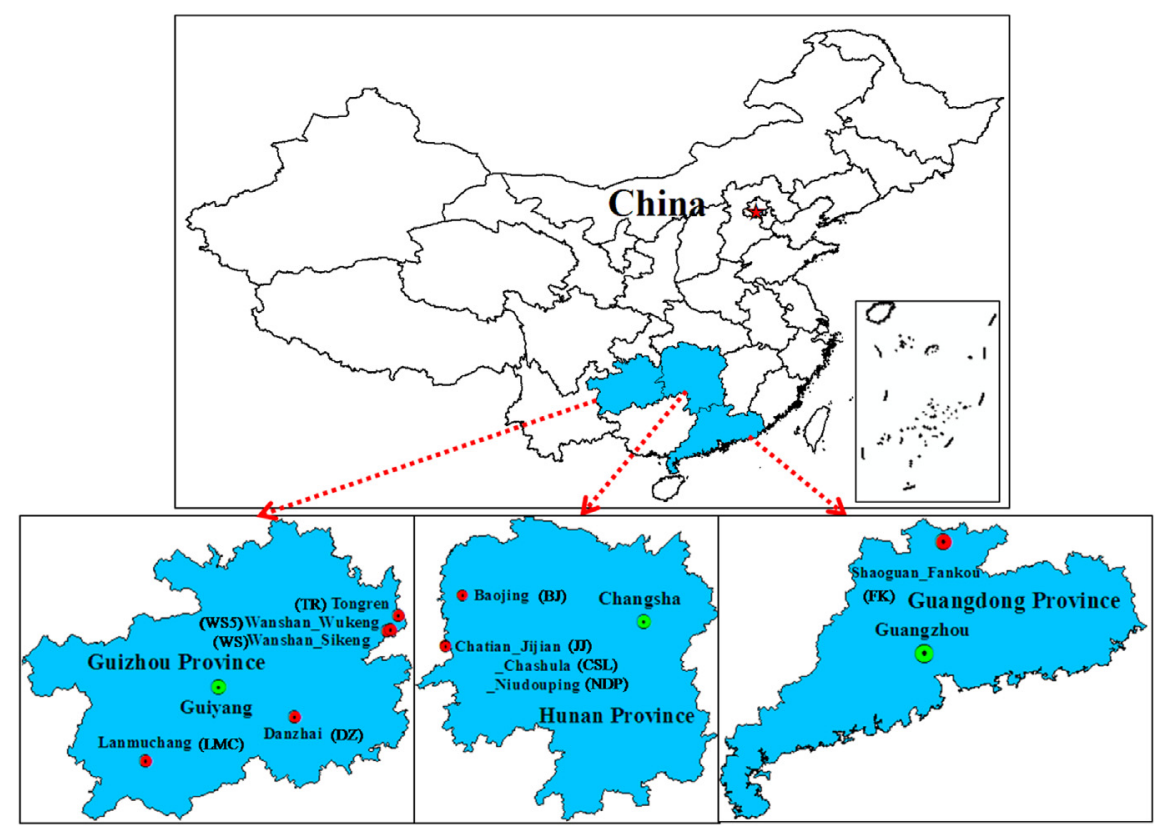

Fig. 1. Map of study regions. (•) indicates a sampling site. 
collected from one individual paddy field except for WS, LMC and FK, where three samples were collected from one paddy field. The selected rice paddy fields were all located near the sedimentation tanks, $\mathrm{Hg}$ smelting residues or $\mathrm{Hg}$ ores of $\mathrm{Hg}$ mines, mostly within the distance of $100-500 \mathrm{~m}$ and some even just below the sedimentation tank dam.

Rice grains were firstly separated from the rice plant using a scalpel. Rice stalk and leaf were then cut down from above water surface $4 \mathrm{~cm}$ (if no water was present, then at $6 \mathrm{~cm}$ above ground). Afterward, the rice plant was pulled out, and soil sample was collected around the root by hand wearing a disposable polyethylene glove. Finally, rice root was cut from the rest of the stalk. Therefore, a total of 595 samples were obtained, including 440 rice tissue samples and 155 soil samples from the root zone.

All rice tissue samples were preliminarily cleaned with drinking water in situ and then thoroughly with ultrapure water after carrying to the laboratory, and finally freeze-dried at $-50{ }^{\circ} \mathrm{C}$ (Alpha 1-2 LD plus, Christ, Germany). In addition, rice seeds (brown rice) were separated from the husks using a decorticating machine (JLG-1, China). Rice seeds were ground to 120 meshes per inch (IKA-A11 basic, IKA Germany), while root, stalk \& leaf and husk samples were cut into very small pieces using a scalpel, because they were too light to be ground within a grinder. Soil samples were sealed in situ, air dried in the laboratory and then ground to 80 meshes per inch. During the whole process, precautions were taken to avoid any cross-contamination. The decorticating machine and the grinder were both thoroughly cleaned after each sample. After preparation, the powdered samples were sealed in polyethylene bags and stored in a $-20{ }^{\circ} \mathrm{C}$ refrigerator for further analysis.

\subsection{Analytical methods}

\subsection{1. $\mathrm{THg}$ analysis}

For $\mathrm{THg}$ in rice tissues, microwave digestion was used. Approximately $0.1 \mathrm{~g}$ of plant tissue was weighed, and $3 \mathrm{~mL}$ of $\mathrm{HNO}_{3}$ and $3 \mathrm{~mL}$ of $\mathrm{H}_{2} \mathrm{O}_{2}$ were added. Then the tissue was microwave digested (MARSX, CEM, USA). For THg in soil, ampule-sealing digestion was adopted (Jones et al., 1995; Liu et al., 2009). Approximately $0.1 \mathrm{~g}$ of soil was weighed into a $20 \mathrm{~mL}$ ampoule, and then $2 \mathrm{~mL}$ of $\mathrm{HNO}_{3}$ and $1 \mathrm{~mL}$ of ultrapure water were added. The ampoule was predigested, sealed using a RFJ model manual ampoule sealer (Jishou Zhongcheng Pharmacy Machine Co., Ltd., China) and finally heated for $2 \mathrm{~h}$ at $105{ }^{\circ} \mathrm{C}$ in an autoclave. After dilution, the concentrations of $\mathrm{THg}$ were determined with an AFS-8130 cold vapor atomic fluorescence spectrometer (CVAFS, Beijing Titan Instruments Co., Ltd., China).

\subsection{2. $\mathrm{MeHg}$ analysis}

For MeHg in rice tissues, $\mathrm{KOH} / \mathrm{CH}_{3} \mathrm{OH}$ was used for MeHg extraction. Approximately $0.1 \mathrm{~g}$ of plant tissue was extracted with $4 \mathrm{~mL}$ of $25 \%(\mathrm{~m} / \mathrm{v}) \mathrm{KOH} / \mathrm{CH}_{3} \mathrm{OH}$ solution by shaking for $4 \mathrm{~h}$ at $37^{\circ} \mathrm{C}$ and $240 \mathrm{rpm}$. For $\mathrm{MeHg}$ in soil, approximately $1.0 \mathrm{~g}$ of soil was digested in a mixture of $5 \mathrm{~mL}$ of $18 \% \mathrm{KBr}$ (in $5 \% \mathrm{H}_{2} \mathrm{SO}_{4}$ ) and $1 \mathrm{~mL} 1 \mathrm{~mol} \mathrm{~L}^{-1}$ $\mathrm{CuSO}_{4}$ for $1 \mathrm{~h}$. Then $10 \mathrm{~mL}$ of $\mathrm{CH}_{2} \mathrm{Cl}_{2}$ was added and $\mathrm{MeHg}$ was extracted into $\mathrm{CH}_{2} \mathrm{Cl}_{2}$ phase by shaking for $1 \mathrm{~h}$. After centrifuging and filtering, $25 \mathrm{~mL}$ ultrapure water was added into $5 \mathrm{~mL}$ of the $\mathrm{CH}_{2} \mathrm{Cl}_{2}$ phase and $\mathrm{MeHg}$ was finally back-extracted into water phase by heating at $65{ }^{\circ} \mathrm{C}$ overnight. After dilution, the concentrations of $\mathrm{MeHg}$ were determined with MERX Automatic Methylmercury System (Brooks Rand Laboratories, Seattle, WA) following EPA 1630 method (USEPA, 2001).

\subsubsection{Water soluble $\mathrm{Hg}$ analysis}

The determination of water soluble $\mathrm{Hg}(\mathrm{Hg}-\mathrm{w})$ in soil followed previously published methods (Bloom et al., 2003; Shi et al., 2005). Briefly, approximately $2.0 \mathrm{~g}$ of soil was extracted in $20 \mathrm{~mL}$ of ultrapure water by shaking for $18 \mathrm{~h}$, followed by centrifuging at $3000 \mathrm{rpm}$ for $15 \mathrm{~min}$. The upper extract was filtered through a 0.45 $\mu \mathrm{m}$ membrane filter. Then $8 \mathrm{~mL}$ of filtered solution was further digested in $1 \mathrm{~mL}$ of $\mathrm{HNO}_{3}$ and $0.1 \mathrm{~mL}$ of $\mathrm{BrCl}$ overnight. The solution was finally diluted and detected with the AFS-8130 CVAFS.

\subsection{Quality control and statistical analysis}

For the analytical quality control in $\mathrm{THg}$ and $\mathrm{MeHg}$ determination, certified reference materials (CRMs), reagent and method blanks and sample replicates were all conducted as part of the analytical procedure. Table 1 lists the detailed information of the CRMs and the obtained results. Recoveries of CRMs were in the range 89.9-108.5\% for THg and $80.0-103.9 \%$ for $\mathrm{MeHg}$. The relative standard deviation (RSD) for duplicate samples analysis ranged from 4.0 to $8.0 \%$ and from 4.0 to $12.0 \%$ for $\mathrm{THg}$ and $\mathrm{MeHg}$, respectively.

Statistical analysis of the data was accomplished by using the SPSS 16.0 software and Origin 8.0 software. Principal component analysis (PCA) and correlation analysis were adopted for investigating potential relationships among the data.

\section{Results and discussion}

\section{1. $\mathrm{THg}$ and $\mathrm{MeHg}$ in rice tissues}

Concentrations of $\mathrm{THg}$ and $\mathrm{MeHg}$ in rice tissues from the ten mining areas varied significantly, especially for the first four sites. The average concentrations of $\mathrm{THg}$ in rice seed (brown rice) were mostly higher than the maximum permissible limit in China of $20 \mu \mathrm{g} \mathrm{kg}^{-1}$ for crops (GB 2762-2005), except for FK, where only one of eighteen samples exceeded the limit. Moreover, the tolerable intake for $\mathrm{MeHg}$ recommended by FAO/WHO (FAO/WHO, 2011; WHO, 2007) is $1.6 \mu \mathrm{g} \mathrm{kg}^{-1}$ bodyweight per week and the USEPA reference dose (RfD) for $\mathrm{MeHg}$ is $0.1 \mu \mathrm{g} \mathrm{kg}{ }^{-1}$ bodyweight per day (USEPA, 1997b). Supposing that the average daily intake of rice was $250 \mathrm{~g}$ and the average bodyweight was $60 \mathrm{~kg}$, the daily MeHg intake in WS (MeHg: $10.8-132.4 \mu \mathrm{g} \mathrm{kg}^{-1}$ ) would be in the range $0.04-$ $0.6 \mu \mathrm{g} \mathrm{kg}^{-1}$, with the mean value of $0.13 \mu \mathrm{g} \mathrm{kg}^{-1}$ (if converted into weekly intake, in the range $0.3-3.9 \mu \mathrm{g} \mathrm{kg}^{-1}$ ), which mostly exceeded both the FAO/WHO and USEPA recommended limits. The high levels of $\mathrm{THg}$ and $\mathrm{MeHg}$ implied serious $\mathrm{Hg}$ contamination in rice paddy fields of selected sampling areas and could pose potential health threat.

For the first four sites, the highest mean $\mathrm{THg}$ concentration in seed was observed in WS $\left(93.6 \pm 114.2 \mu \mathrm{g} \mathrm{kg}^{-1}\right)$, with the maximum of $584.4 \mu \mathrm{g} \mathrm{kg}^{-1}$, which was quite close to previously reported levels (569 $\mathrm{g} \mathrm{kg}^{-1}$, Horvat et al., 2003). The lowest one was found in FK $\left(16.0 \pm 4.1 \mu \mathrm{g} \mathrm{kg}^{-1}\right)$ with the range 10.4$27.6 \mu \mathrm{g} \mathrm{kg}^{-1}$. The average $\mathrm{THg}$ levels in rice seed in $\mathrm{DZ}$ $\left(85.8 \pm 43.6 \mu \mathrm{g} \mathrm{kg}^{-1}\right)$ and LMC $\left(22.0 \pm 5.3 \mu \mathrm{g} \mathrm{kg}^{-1}\right)$ were both lower than those in WS but higher than those in FK. For MeHg, the highest mean concentration was again found in WS $\left(30.4 \pm 26.5 \mu \mathrm{g} \mathrm{kg}^{-1}\right)$, with the maximum of $132.4 \mu \mathrm{g} \mathrm{kg}{ }^{-1}$, which also accorded with previous report (145 $\mu \mathrm{g} \mathrm{kg}^{-1}$. Horvat et al., 2003), followed by DZ $\left(20.8 \pm 9.3 \mu \mathrm{g} \mathrm{kg}^{-1}\right)$, then LMC $\left(12.3 \pm 4.9 \mu \mathrm{g} \mathrm{kg}^{-1}\right)$, and finally FK $\left(2.0 \pm 0.5 \mu \mathrm{g} \mathrm{kg}{ }^{-1}\right)$.

As a whole, $\mathrm{Hg}$ contamination degrees in rice plants were quite different among the ten mining areas. For the first four sites, the average concentrations of $\mathrm{THg}$ and $\mathrm{MeHg}$ in rice tissues followed the order: WS $>$ DZ $>$ LMC $>$ FK. For the other six sites, the order

Table 1

List of CRMs in the present study and the results obtained $\left(\mu \mathrm{g} \mathrm{kg}^{-1}\right)$.

\begin{tabular}{|c|c|c|c|c|c|c|c|}
\hline \multirow[t]{2}{*}{ CRM } & \multirow[t]{2}{*}{ Producer } & \multirow[t]{2}{*}{ Description } & \multirow[t]{2}{*}{$N$} & \multicolumn{2}{|l|}{$\mathrm{THg}$} & \multicolumn{2}{|l|}{$\mathrm{MeHg}$} \\
\hline & & & & Obtained value & Certified value & Obtained value & Certified value \\
\hline DORM-3 & NRCC & Fish protein & 4 & $377.2 \pm 21.5$ & $382 \pm 60$ & $318.7 \pm 38.2$ & $355 \pm 56$ \\
\hline TORT-2 & NRCC & Lobster Hepatopancreas & 4 & $269.2 \pm 13.2$ & $270 \pm 60$ & $126.9 \pm 5.3$ & $152 \pm 13$ \\
\hline IAEA-405 & IAEA & Estuarine sediment & 3 & $825.6 \pm 36.9$ & $810 \pm 40$ & & \\
\hline ERM-CC580 & IRMM & Estuarine sediment & 6 & & & $72.9 \pm 5.5$ & $75.5 \pm 3.7$ \\
\hline GBW07310 & NCRM & Sediment & 6 & $291.5 \pm 12.7$ & $280 \pm 40$ & & \\
\hline GBW07312 & NCRM & Sediment & 4 & $57.5 \pm 4.8$ & $56 \pm 8$ & & \\
\hline
\end{tabular}

NRCC: National Research Council Canada.

IAEA: International Atomic Energy Agency.

IRMM: Institute for Reference Materials and Measurements.

NCRM: National information center for Certified Reference Materials, China. 
was: WS5 $>$ JJ $>$ CSL $>$ TR $>$ NDP $>$ BJ. The differences of both THg and $\mathrm{MeHg}$ in rice tissues among the sampling sites were significant $(P<0.01)$. The $\mathrm{THg}$ and $\mathrm{MeHg}$ concentrations in rice from the six sites were lower than those from WS, and close to those from DZ and LMC, but higher than the ones from FK.

\section{2. $\mathrm{THg}, \mathrm{MeHg}$ and $\mathrm{Hg}-\mathrm{w}$ in soil}

Table 2 shows the THg, MeHg and water soluble Hg (Hg-w) levels in soil samples. THg levels varied between the sites and were about one order of magnitude higher than those in roots. Comparing with some other important mines in the world such as Almadén, Spain (Millán et al., 2006) and Idrija, Slovenia (Biester et al., 1999), it could be found that these $\mathrm{THg}$ values are normal in $\mathrm{Hg}$ mining areas. However, these values were significantly high if compared with those in common soils from non-mining areas in China (Shi et al., 2013). For the first four sites, the mean THg concentrations in soil were $101,734.3 \pm 60,220.7 \mu \mathrm{g} \mathrm{kg}^{-1}$ in WS (in the range $27,902.3-$ $294,892.5 \mu \mathrm{g} \mathrm{kg}^{-1}$ ), $14,425.1 \pm 7,809.1 \mu \mathrm{g} \mathrm{kg}{ }^{-1}$ in $\mathrm{DZ}$ (in the range $7,655.8-33,888.2 \mu \mathrm{g} \mathrm{kg}^{-1}$ ), 7,859.1 $\pm 5,227.0 \mu \mathrm{g} \mathrm{kg}^{-1}$ in LMC (in the range $1,896.6-15,979.9 \mu \mathrm{g} \mathrm{kg}^{-1}$ ) and 2,287.7 $\pm 1,466.5 \mu \mathrm{g} \mathrm{kg}^{-1}$ in FK (in the range $587.1-5,524.4 \mu \mathrm{g} \mathrm{kg}^{-1}$ ). The mean $\mathrm{THg}$ levels in soil from the first four sites also followed the same order as rice tissues: WS $>$ DZ $>$ LMC $>$ FK $(P<0.01)$, and the average THg concentrations in soil from the other six sites followed the order: $\mathrm{TR}>\mathrm{JJ}>\mathrm{CSL}>\mathrm{BJ}>$ WS5 $>\mathrm{NDP}(P<0.01)$.

The MeHg levels were mostly below $10 \mu \mathrm{g} \mathrm{kg}^{-1}$ in soils. The percentages of $\mathrm{MeHg}$ in $\mathrm{THg}$ were much lower in soils $(0.002 \%-$ $1.4 \%$, mean: $0.09 \% \pm 0.2 \%)$ than those in roots $(0.2 \%-8.9 \%$, mean: $1.3 \% \pm 1.6 \%$ ). The mean $\mathrm{MeHg}$ concentrations in soil were still highest in WS (1.7-16.6 $\mu \mathrm{g} \mathrm{kg}^{-1}$, mean: $\left.8.4 \pm 3.9 \mu \mathrm{g} \mathrm{kg}^{-1}\right)$, followed by LMC $\left(2.2-13.1 \mu \mathrm{g} \mathrm{kg}^{-1}\right.$, mean: $\left.6.0 \pm 3.6 \mu \mathrm{g} \mathrm{kg}^{-1}\right)$, then FK $(0.3-$ $\left.8.5 \mu \mathrm{g} \mathrm{kg}-1,2.6 \pm 2.8 \mu \mathrm{g} \mathrm{kg}^{-1}\right)$, and finally DZ $\left(1.9-3.8 \mu \mathrm{g} \mathrm{kg}^{-1}\right.$, $\left.2.5 \pm 0.6 \mu \mathrm{g} \mathrm{kg}^{-1}\right)$. It was obvious that the mean MeHg levels in soil varied between mining areas, but did not follow the same order as mentioned above.

Water soluble $\mathrm{Hg}(\mathrm{Hg}-\mathrm{w})$ is more easily bioavailable and might serve as a main substrate for methylation of $\mathrm{IHg}$ (Wallschlager et al., 1998; Boszke et al., 2006; Covelli et al., 2009). In this work, the concentrations of Hg-W in the first four sites soils $(n=65)$ were determined. As shown in Table 2, Hg-w levels were relatively low in soil, mostly accounting for less than $0.1 \%$ of $\mathrm{THg}$. The highest concentration of $\mathrm{Hg}-\mathrm{W}$ was detected in WS (6.5-384.0 $\mu \mathrm{g} \mathrm{kg}^{-1}$, mean: $\left.155.9 \pm 116.9 \mu \mathrm{g} \mathrm{kg}^{-1}\right)$, followed by DZ $\left(0.3-21.9 \mu \mathrm{g} \mathrm{kg}-1\right.$, mean: $\left.5.3 \pm 7.3 \mu \mathrm{g} \mathrm{kg}^{-1}\right)$, LMC $(0.3-$ $7.7 \mu \mathrm{g} \mathrm{kg}{ }^{-1}$, mean: $\left.2.2 \pm 2.3 \mu \mathrm{g} \mathrm{kg}{ }^{-1}\right)$, and FK $\left(0.1-9.3 \mu \mathrm{g} \mathrm{kg}^{-1}\right.$, mean: $\left.2.8 \pm 2.9 \mu \mathrm{g} \mathrm{kg}^{-1}\right)$. The $\mathrm{Hg}-\mathrm{w}$ levels in these four sites followed the same order as $\mathrm{THg}$, and the differences were significant among these four sites $(P<0.01)$.
Table 3

Pearson's correlation matrix among THg levels in tissues of rice plant and paddy soil, together with $\mathrm{Hg}-\mathrm{w}(n=65)$.

\begin{tabular}{lllllll}
\hline & Stalk \& leaf & Seed & Husk & Root & Soil & Hg-w \\
\hline Stalk \& leaf & 1 & $0.353^{\mathrm{a}}$ & $0.717^{\mathrm{a}}$ & $0.814^{\mathrm{a}}$ & $0.861^{\mathrm{a}}$ & $0.551^{\mathrm{a}}$ \\
Seed & $0.353^{\mathrm{a}}$ & 1 & $0.442^{\mathrm{a}}$ & 0.214 & $0.299^{\mathrm{b}}$ & $0.303^{\mathrm{b}}$ \\
Husk & $0.717^{\mathrm{a}}$ & $0.442^{\mathrm{a}}$ & 1 & $0.614^{\mathrm{a}}$ & $0.529^{\mathrm{a}}$ & $0.547^{\mathrm{a}}$ \\
Root & $0.814^{\mathrm{a}}$ & 0.214 & $0.614^{\mathrm{a}}$ & 1 & $0.892^{\mathrm{a}}$ & $0.582^{\mathrm{a}}$ \\
Soil & $\mathbf{0 . 8 6 1}^{\mathrm{a}}$ & $\mathbf{0 . 2 9 9}^{\mathrm{b}}$ & $\mathbf{0 . 5 2 9}^{\mathrm{a}}$ & $\mathbf{0 . 8 9 2}^{\mathrm{a}}$ & $\mathbf{1}^{\mathrm{a}}$ & $\mathbf{0 . 6 1 1}^{\mathrm{a}}$ \\
Hg-w & $\mathbf{0 . 5 5 1}^{\mathrm{a}}$ & $\mathbf{0 . 3 0 3}^{\mathrm{b}}$ & $\mathbf{0 . 5 4 7}^{\mathrm{a}}$ & $\mathbf{0 . 5 8 2}^{\mathrm{a}}$ & $\mathbf{0 . 6 1 1}^{\mathrm{a}}$ & $\mathbf{1}$ \\
\hline
\end{tabular}

${ }^{\text {a }}$ Correlation is significant at the 0.01 level (2-tailed).

b Correlation is significant at the 0.05 level (2-tailed).

\subsection{Bioavailability of $\mathrm{Hg}$ in paddy soil}

The Pearson's correlations between $\mathrm{Hg}-\mathrm{w}$ in soil and $\mathrm{Hg}$ in rice tissues are shown in Tables 3 and 4. Although Hg-w levels in soil were relatively low, they were significantly positively correlated with THg in soil $(r=0.611, p<0.01, n=65)$, root $(r=0.582$, $p<0.01, n=65)$, stalk \& leaf $(r=0.551, p<0.01, n=65)$, husk $(r=0.547, p<0.01, n=65)$ and seed $(r=0.303, p<0.05, n=65)$. The correlation coefficient values were quite similar to those between soil THg and rice tissues (Table 3, in bold), and followed the same order of soil $>$ root $>$ stalk \& leaf $>$ husk $>$ seed. This indicated that the $\mathrm{Hg}-\mathrm{w}$ contributed a great part of bioavailability of soil THg, and could be an important source for THg accumulation in rice tissues.

On the other hand, $\mathrm{Hg}-\mathrm{w}$ was also significantly positively correlated with $\mathrm{MeHg}$ in root $(r=0.725, p<0.01, n=65)$, soil $(r=0.530, p<0.01, n=65)$, seed $(r=0.468, p<0.01, n=65)$, husk $(r=0.296, p<0.05, n=65)$, and stalk \& leaf $(r=0.284, p<0.05$, $n=65)$, following the order of root $>$ soil $>$ seed $>$ husk $>$ stalk $\&$ leaf. The correlations between $\mathrm{Hg}-\mathrm{W}$ and $\mathrm{MeHg}$ in the rice plant tissues were much more significant than those between $\mathrm{MeHg}$ in the soil and the plant tissues (Table 4, in bold). In addition, positive correlations were present between $\mathrm{Hg}-\mathrm{W}$ and $\mathrm{MeHg}$ in stalk \& leaf and husk, but not between soil $\mathrm{MeHg}$ and $\mathrm{MeHg}$ in stalk \& leaf and husk. Therefore, more attention should be paid to $\mathrm{Hg}-\mathrm{W}$ in soil in future studies of $\mathrm{MeHg}$ accumulation in rice plants.

\subsection{Accumulation pathways of $\mathrm{THg}$ and $\mathrm{MeHg}$ in rice plants}

The distributions of $\mathrm{THg}$ and $\mathrm{MeHg}$ in different rice tissues from the ten sites are shown in Figs. 2 and 3, respectively. It could be found that $\mathrm{THg}$ levels in rice tissues from all these sites basically followed the same trend: root $>$ stalk \& leaf $>$ husk $>$ seed, while $\mathrm{MeHg}$ were distributed in different trend: root $>$ seed $>$ stalk $\&$ leaf $>$ husk. The distribution tendency of THg is in agreement with previous studies (Sierra et al., 2008, 2011; Zornoza et al., 2009). The

Table 2

Concentrations of THg, MeHg and $\mathrm{Hg}-\mathrm{w}\left(\mu \mathrm{g} \mathrm{kg}^{-1}\right)$ in rice paddy soil from ten sampling sites.

\begin{tabular}{|c|c|c|c|}
\hline Sampling sites & $\mathrm{THg}^{\mathrm{a}}$ & $\mathrm{MeHg}^{\mathrm{a}}$ & $\mathrm{Hg}-\mathrm{w}^{\mathrm{a}}$ \\
\hline Danzhai $(\mathrm{DZ})(n=11)$ & $14,425.1 \pm 7,809.1(7,655.8-33,888.2)$ & $2.5 \pm 0.6(1.9-3.8)$ & $5.3 \pm 7.3(0.3-21.9)$ \\
\hline Wanshan_sikeng (WS) $(n=21)$ & $101,734.3 \pm 60,220.7(27,902.3-294,892.5)$ & $8.4 \pm 3.9(1.7-16.6)$ & $155.9 \pm 116.9(6.5-384.0)$ \\
\hline Lanmuchang (LMC) $(n=15)$ & $7,859.1 \pm 5,227.0(1,896.6-15,979.9)$ & $6.0 \pm 3.6(2.2-13.1)$ & $2.2 \pm 2.3(0.3-7.7)$ \\
\hline Fankou $(\mathrm{FK})(n=18)$ & $2,287.7 \pm 1,466.5(587.1-5,524.4)$ & $2.6 \pm 2.8(0.3-8.5)$ & $2.8 \pm 2.9(0.1-9.3)$ \\
\hline Baojing (BJ) $(n=15)$ & $32,687.0 \pm 2,056.5(28,986.0-35,905.2)$ & $4.1 \pm 0.7(3.0-6.2)$ & \\
\hline Chashula (CSL) $(n=15)$ & $63,837.3 \pm 13,226.5(50,784.6-85,693.8)$ & $6.2 \pm 1.4(4.5-10.9)$ & \\
\hline Jijian $(J J)(n=15)$ & $155,127.9 \pm 11,708.0(138,051.5-172,471.9)$ & $8.2 \pm 0.7(6.5-9.8)$ & \\
\hline Niudouping (NDP) $(n=15)$ & $13,810.7 \pm 2,402.0(6,827.6-16,706.6)$ & $4.5 \pm 0.7(2.8-6.3)$ & \\
\hline Tongren $(\mathrm{TR})(n=15)$ & $186,809.0 \pm 16,973.6(162,987.0-217,338.7)$ & $6.7 \pm 1.2(4.7-9.1)$ & \\
\hline Wanshan_wukeng (WS5) $(n=15)$ & $25,066.7 \pm 7,317.0(15,411.9-34,933.3)$ & $4.9 \pm 2.1(1.6-10.4)$ & \\
\hline
\end{tabular}

\footnotetext{
${ }^{\text {a }}$ Mean \pm SD (range).
} 
Table 4

Pearson's correlation matrix among MeHg levels in tissues of rice plant and paddy soil, together with Hg-w $(n=65)$.

\begin{tabular}{|c|c|c|c|c|c|c|}
\hline & Stalk \& leaf & Seed & Husk & Root & Soil & $\mathrm{Hg}-\mathrm{w}$ \\
\hline Stalk \& leaf & 1 & 0.170 & $0.276^{\mathrm{b}}$ & 0.182 & 0.220 & $0.284^{b}$ \\
\hline Seed & 0.170 & 1 & $0.859^{a}$ & $0.524^{a}$ & $0.278^{\mathrm{b}}$ & 0.468 \\
\hline Husk & $0.276^{\mathrm{b}}$ & $0.859^{\mathrm{a}}$ & 1 & $0.337^{\mathrm{a}}$ & 0.174 & $0.296^{\mathrm{b}}$ \\
\hline Root & 0.182 & $0.524^{a}$ & $0.337^{\mathrm{a}}$ & 1 & $0.569^{a}$ & $0.725^{a}$ \\
\hline Soil & 0.220 & $0.278^{b}$ & 0.174 & $0.569^{\mathrm{a}}$ & 1 & 0.530 \\
\hline $\mathrm{Hg}-\mathrm{w}$ & $0.284^{b}$ & $0.468^{a}$ & $0.296^{\mathrm{b}}$ & $0.725^{a}$ & $0.530^{a}$ & 1 \\
\hline
\end{tabular}

a Correlation is significant at the 0.01 level (2-tailed)

b Correlation is significant at the 0.05 level (2-tailed).

average THg levels in seed were lower than those in husk, but the average MeHg levels in seed were significantly higher than those in husk. This obvious discrepancy indicated that $\mathrm{IHg}$ and $\mathrm{MeHg}$ might be accumulated into rice plants following different pathways. Relevant evidence have shown that organic Hg could be transported to plant tissues much more easily than $\mathrm{IHg}$ (Schwesig and Krebs, 2003) and the phytochelatins that detoxify plants from heavy metal could sequester divalent $\mathrm{Hg}$ ion, instead of $\mathrm{MeHg}$ (Krupp et al., 2009).

The distribution of $\mathrm{THg}$ in rice tissues and soils followed the trend of decreasing from bottom to top (soil $>$ root $>$ stalk $\&$ leaf $>$ husk $>$ seed), which was similar to the absorption and transport of water and inorganic salt in plants. In addition, the correlations between $\mathrm{THg}$ in rice tissues and those in soil also
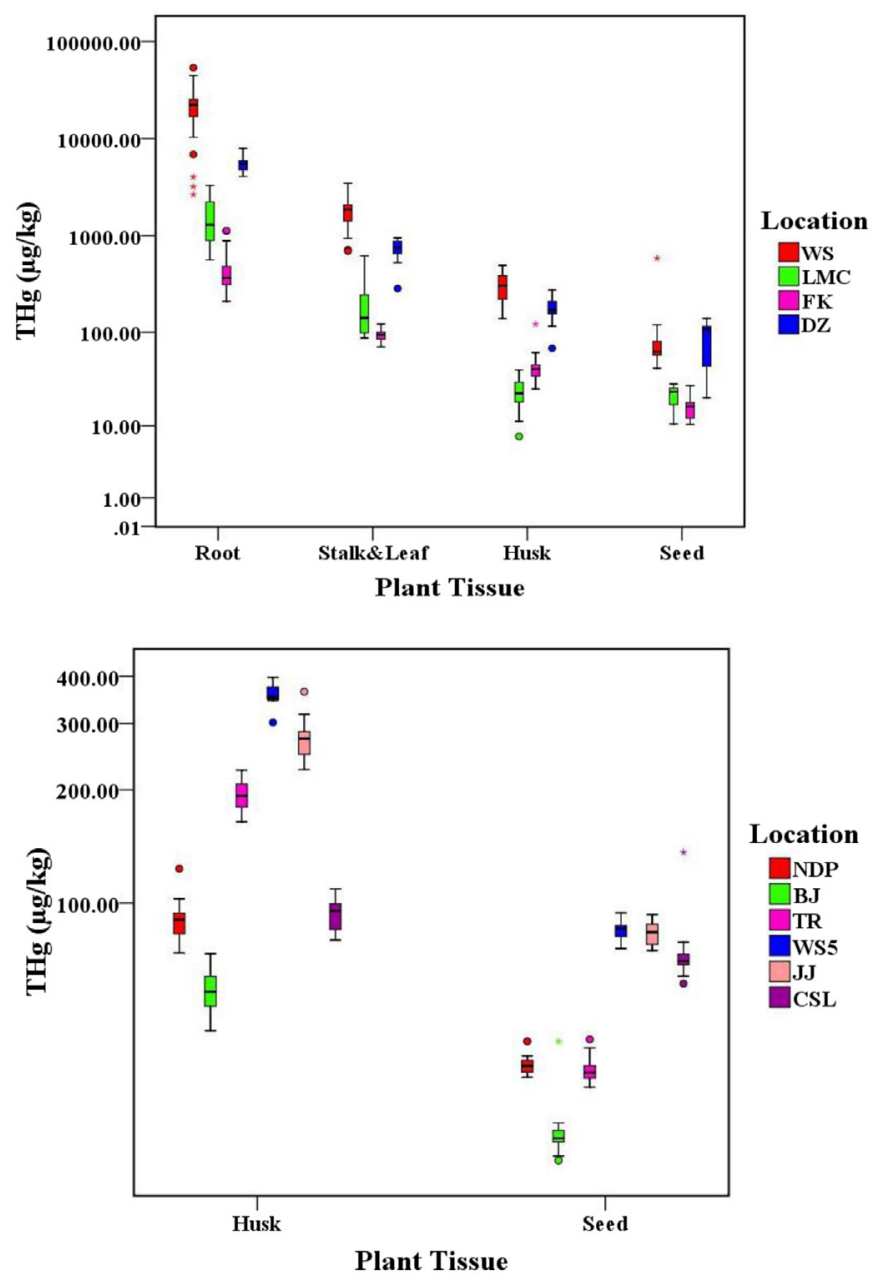

Fig. 2. Distribution of THg in different tissues of rice plants. followed the similar trend: $\operatorname{root}(r=0.892, p<0.01, n=65)>$ stalk \& leaf $(r=0.861, p<0.01, n=65)>$ husk $(r=0.529, p<0.01$, $n=65)>$ seed $(r=0.299, p<0.05, n=65)$ (Table 3$)$. Previous studies have found that $\mathrm{Hg}$ levels in root were directly associated with Hg levels in soil (Fay and Gustin, 2007) and $\mathrm{Hg}$ in rice paddy soil was the main source of IHg in root (Meng et al., 2010). On the other hand, the husk and stalk \& leaf could accumulate $\mathrm{Hg}$ from air and total gaseous mercury (TGM) concentrations might affect IHg levels in husk and stalk \& leaf (Fay and Gustin, 2007; Meng et al., 2010). These together suggested that IHg in rice plants was mainly absorbed and transported from soil by root accompanying with the absorption of water or inorganic salt through free diffusion mechanism, and partly accumulated from air by stalk \& leaf and husk. However, this still needs to be further demonstrated.

In order to compare the accumulation ability for $\mathrm{MeHg}$ of different rice tissues, the percentages of $\mathrm{MeHg}$ in $\mathrm{THg}$ (\% $\mathrm{MeHg}$ ) were calculated. As shown in Fig. 4, the average percentage of MeHg in seed reached up to $30.9 \%$, much higher than those in root $(0.7 \%)$, stalk \& leaf $(0.9 \%)$ and husk (2.9\%). This showed that rice seed had the highest ability for the accumulation of $\mathrm{MeHg}$. As shown in Table 4, the concentrations of $\mathrm{MeHg}$ in seed were significantly correlated with those in husk $(r=0.859, p<0.01$, $n=65)$, root $(r=0.524, p<0.01, n=65)$, and soil $(r=0.278$, $p<0.05, n=65$ ). The MeHg levels in root were also positively correlated with those in soil $(r=0.569, p<0.01, n=65)$. This confirmed that MeHg in soil is a potential source to rice root and finally to rice seed. However, according to our above analysis on $\mathrm{Hg}$
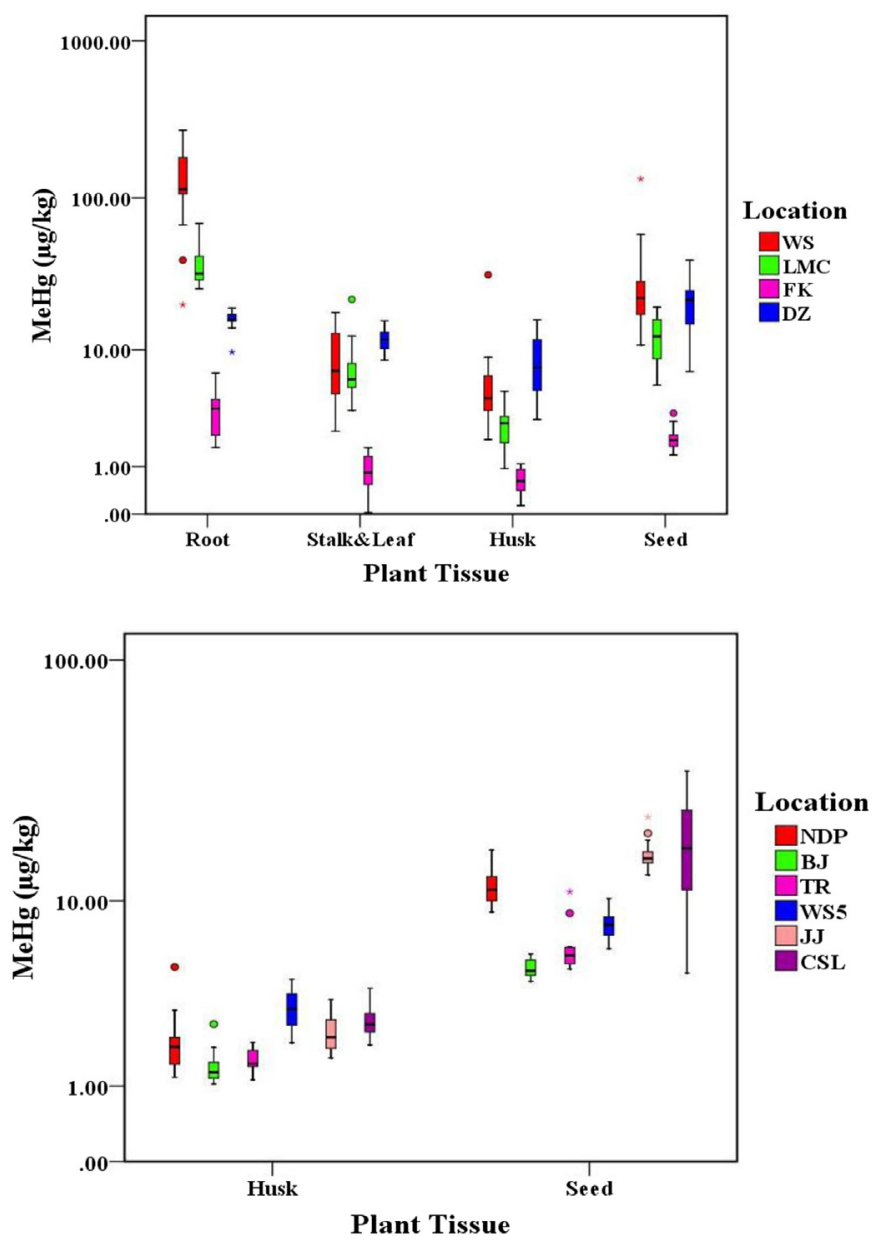

Fig. 3. Distribution of MeHg in different tissues of rice plants. 
bioavailability in soil, $\mathrm{Hg}-\mathrm{w}$ in soil showed more significant correlations with $\mathrm{MeHg}$ in rice tissues than soil $\mathrm{MeHg}$ and was more bioavailable to rice plants. Therefore, $\mathrm{Hg}-\mathrm{w}$ may play more important roles than $\mathrm{MeHg}$ in soil for the accumulation of $\mathrm{MeHg}$ in rice tissues. This could probably be due to the fact that Hg-w might serve as a major substrate for the methylation process of $\mathrm{IHg}$ (Wallschlager et al., 1998; Boszke et al., 2006; Covelli et al., 2009). More works will be needed to further investigate the position for the methylation of Hg-w, in vitro (rhizosphere soil) or in vivo (root, stalk, leaf, husk or seed).

Principal component analysis (PCA) was performed to investigate the relationships between the variables. Table 5 shows the component score coefficient matrix of PCA. Fig. 5 shows the plots of PCA by using THg and MeHg data matrix in rice tissues and soils from the first four sampling sites. For THg, two principal components explained cumulatively $92.7 \%$ of the total variance, and PC1 and PC2 accounted for $85.8 \%$ and $6.9 \%$, respectively. Rice tissues and paddy soil could be divided into three groups according to loading values of PC1 and PC2 from THg data set. Root and soil were in one group with relatively high loadings in PC1 but relatively low loadings in PC2. Seed and husk were in another group that was completely different from root and soil, with relatively high loadings in PC2 but relatively low loadings in PC1. Stalk \& leaf was singly in one group, with loadings in both PC1 and PC2 between these two groups. It could be inferred that PC1 might be attributed to the impact from $\mathrm{Hg}$ in paddy soil, playing the dominant role $(85.8 \%)$, while PC2 could be from other factors such as ambient air Hg (Fay and Gustin, 2007; Meng et al., 2010). Therefore, the principal component analysis of THg further demonstrated that the levels of $\mathrm{Hg}$ in soil was the main source of $\mathrm{THg}$ to rice plants, although it might also be affected by the other factors.

For MeHg, two principal components accounting for $74.1 \%$ and $13.4 \%$ respectively, explained cumulatively $87.5 \%$ of the total variance. Similar to THg analysis above, rice tissues and paddy soil could also be divided into three groups according to loadings in PC1 and PC2 from MeHg data set. According to the above analysis, PC2 was attributed to MeHg in paddy soil, while PC1 might be attributed to other factors, such as the abilities of rice tissues for the transportation and accumulation of MeHg. Root and soil described PC2, and stalk \& leaf characterized PC1. Husk and seed were associated with both PC1 and PC2. This indicated that MeHg in paddy soil was a potential source to root, and $\mathrm{MeHg}$ in root and stalk \& leaf might also be affected by other factors. MeHg from both the two sources was finally transported to husk and seed, with seed as the main destination. This was quite similar to the transport of

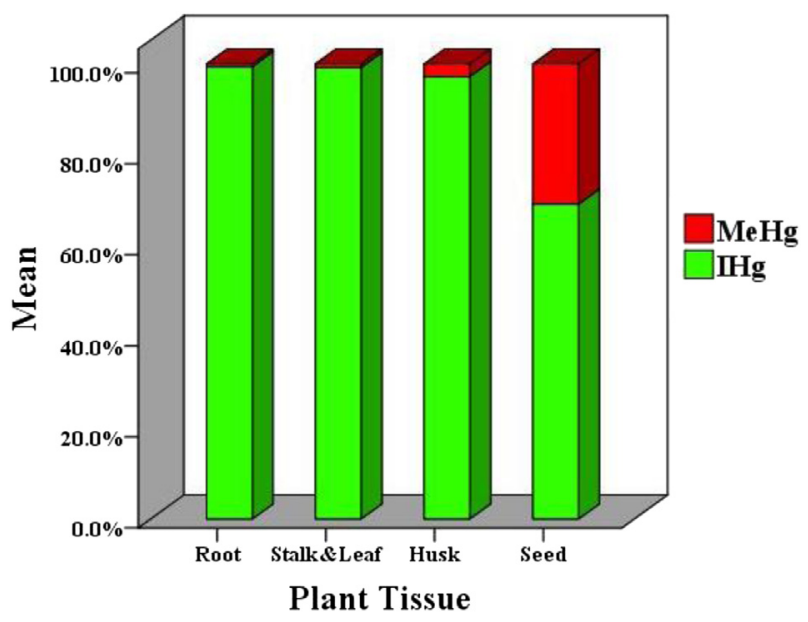

Fig. 4. Percentage of MeHg in THg in different tissues of rice plant.
Table 5

The component score coefficient matrix of PCA and percent variance explained by each factor from concentrations of both $\mathrm{THg}$ and $\mathrm{MeHg}$ in rice tissues and paddy soil.

\begin{tabular}{|c|c|c|c|c|c|c|c|}
\hline \multirow[t]{2}{*}{ Tissues \& soil } & \multicolumn{3}{|c|}{ PCA factors from $\mathrm{THg}$} & \multirow[t]{2}{*}{ Tissues \& soil } & \multicolumn{3}{|c|}{ PCA factors from $\mathrm{MeHg}$} \\
\hline & $\mathrm{E}$ & $\mathrm{F} 1$ & $\mathrm{~F} 2$ & & $\mathrm{E}$ & F1 & F2 \\
\hline Seed & 0.870 & -0.438 & 0.797 & Seed & 0.909 & 0.347 & -0.040 \\
\hline Husk & 0.897 & -0.495 & 0.862 & Husk & 0.850 & 0.372 & -0.091 \\
\hline Stalk \& leaf & 0.950 & 0.338 & -0.038 & Stalk \& leaf & 0.803 & 0.534 & -0.355 \\
\hline Root & 0.963 & 0.659 & -0.406 & Root & 0.871 & 0.013 & 0.393 \\
\hline Soil & 0.959 & 0.652 & -0.398 & Soil & 0.942 & -0.404 & 0.874 \\
\hline $\begin{array}{c}\% \text { of variance } \\
\text { explained }\end{array}$ & & 85.8 & 6.9 & $\begin{array}{l}\% \text { of variance } \\
\text { explained }\end{array}$ & & 74.1 & 13.4 \\
\hline $\begin{array}{l}\text { Cumulative of } \\
\text { total variance }\end{array}$ & & 92.7 & & $\begin{array}{l}\text { Cumulative of } \\
\text { total variance }\end{array}$ & & 87.5 & \\
\hline
\end{tabular}

E, extraction; initial, 1.000; extraction method, principal component analysis.

nutrients to seed in plants, since seed is the final destination of nutrients, especially the endosperm. As reported, $\mathrm{MeHg}$ is present in uncooked rice seed mostly in the form of $\mathrm{CH}_{3} \mathrm{Hg}$-L-cysteinate $\left(\mathrm{CH}_{3} \mathrm{HgCys}\right)$, which was responsible for the transport of $\mathrm{MeHg}$
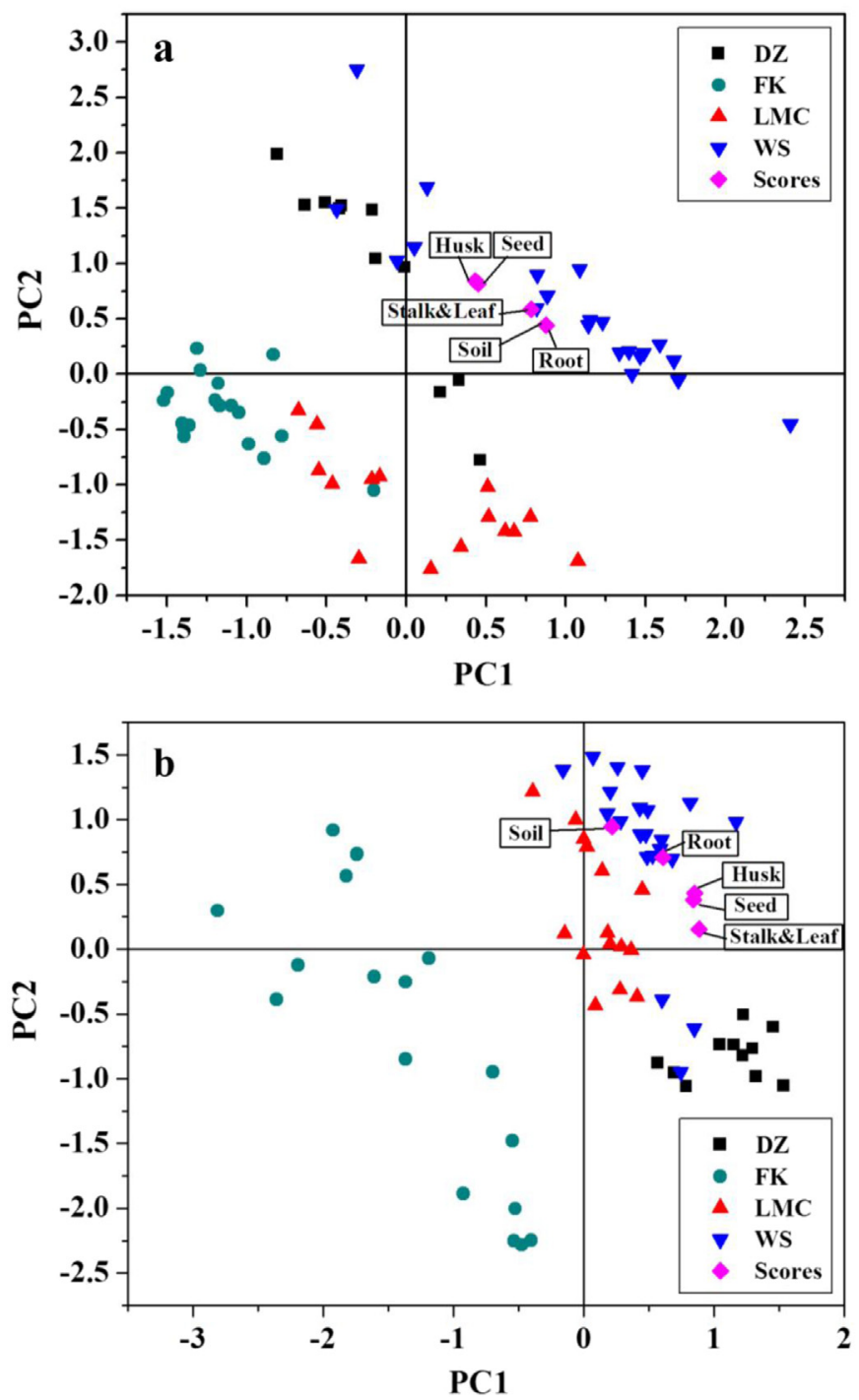

Fig. 5. Plot of principle component analysis. (a) plot by using the data matrix of THg in rice tissues and paddy soil from the first four sites; (b) plot by using the data matrix of $\mathrm{MeHg}$ in rice tissues and paddy soil from the first four sites. Rotation method, varimax with Kaiser Normalization, rotation converged in 3 iterations. 
across the blood-brain and placental barriers (Li et al., 2010). MeHg could infiltrate the endosperm more efficiently than $\mathrm{IHg}$ (Rothenberg et al., 2011) and most MeHg is firstly located in stalk \& leaf and then transferred to seed during the ripening period (Meng et al., 2011). Therefore, MeHg might be combined with some nutrients, but not existed alone in rice seed. The transport of $\mathrm{MeHg}$ from root and stalk \& leaf to rice seed was similar to the transport of nutrients in plants.

From Fig. 5, it can be found that the different sites were individually grouped with only minor overlapping in the plot of PC1 vs PC2. This indicates a perceived discrepancy in both $\mathrm{THg}$ and $\mathrm{MeHg}$ distribution in rice tissues among the different mining areas. In Fig. 5a, DZ was seemingly associated with husk and seed, which was characterized by PC2, and WS described PC1, which was associated with soil and root. However, LMC (relatively high negative in PC2) and FK (relatively high negative in PC1) were not simply characterized by any of the plant tissues. According to the above discussion, in DZ, Hg in ambient air may act as the major source of IHg to rice plants than in the other sites. While in WS, Hg in paddy soil may be the more important source to rice plants. As for LMC and FK, the two pathways might both act as important sources. In Fig. 5b, DZ was characterized by stalk \& leaf, husk and seed, with relatively high positive PC1 and WS, associated with root and soil, was described by PC2. These results revealed that $\mathrm{IHg}$ and $\mathrm{MeHg}$ accumulation processes in rice plants might be affected by the locally specific $\mathrm{Hg}$ contamination conditions. This could be interpreted by the different degrees of $\mathrm{Hg}$ contamination between mining areas as concluded above.

\section{Conclusions}

Although the degree of $\mathrm{Hg}$ contamination varied significantly among different mining areas, rice seed showed the highest ability to accumulate $\mathrm{MeHg}$ in aerial part of the plant. The obvious discrepancy between the distribution trends of $\mathrm{THg}$ and $\mathrm{MeHg}$ indicated different pathways of $\mathrm{IHg}$ and $\mathrm{MeHg}$ accumulation in rice plants. According to the bottom-up order of THg levels in soil and rice tissues, PCA analysis and correlation coefficients of THg concentrations in soil and rice tissues, $\mathrm{IHg}$ in rice plants might be absorbed and transported from soil by root accompanying with the absorption of water or inorganic salt through free diffusion mechanism, and also partly accumulated from air. According to PCA analysis and correlation coefficients among soil $\mathrm{Hg}-\mathrm{W}$, and $\mathrm{MeHg}$ concentrations in soil and rice tissues, $\mathrm{MeHg}$ in rice plants might be affected by both $\mathrm{MeHg}$ and $\mathrm{Hg}-\mathrm{w}$ in soil. Hg-w showed more significant correlations with $\mathrm{MeHg}$ in rice tissues, indicating that $\mathrm{Hg}$ w may play more important roles in the accumulation of $\mathrm{MeHg}$ in rice plants than $\mathrm{MeHg}$ in soil. Further study is needed to investigate the position for the methylation of $\mathrm{Hg}-\mathrm{w}$, in vitro (rhizosphere soil) or in vivo (root, stalk, leaf, husk or seed).

\section{Acknowledgments}

The work described here was supported by the National Basic Research Program of China (2013CB430004 and 2009CB421605) and the National Natural Science Foundation of China (21120102040, 20937002 and 31070450).

\section{References}

Al-Majed, N.B., Preston, M.R., 2000. Factors influencing the total mercury and methyl mercury in the hair of the fishermen of Kuwait. Environ. Pollut. 109, $239-250$.

Biester, H., Gosar, M., Müller, G., 1999. Mercury speciation in tailings of the Idrija mercury mine. J. Geochem. Explor. 65, 195-204.
Bloom, N.S., Preus, E., Katon, J., Hiltner, M., 2003. Selective extractions to assess the biogeochemically relevant fractionation of inorganic mercury in sediments and soils. Anal. Chim. Acta 479, 233-248.

Boszke, L., Kowalski, A., Szczucinski, W., Rachlewicz, G., Lorenc, S., Siepak, J., 2006. Assessment of mercury mobility and bioavailability by fractionation method in sediments from coastal zone inundated by the 26 December 2004 tsunami in Thailand. Environ. Geol. 51, 527-536.

Clarkson, T.W., 1993. Mercury-major issues in environmental-health. Environ. Health Persp. 100, 31-38.

Clarkson, T.W., 1998. Human toxicology of mercury. J. Trace Elem. Exp. Med. 11, 303-317.

CNSA, 1995. Environmental Quality Standard for Soils, GB 15618-1995. Chinese National Standard Agency, Beijing (in Chinese).

CNSA, 2005. Maximum Levels of Contaminants in Foods, GB 2762-2005. Chinese National Standard Agency, Beijing (in Chinese).

Covelli, S., Acquavita, A., Piani, R., Predonzani, S., De Vittor, C., 2009. Recent contamination of mercury in an estuarine environment (Marano lagoon, Northern Adriatic, Italy). Estuar. Coast. Shelf Sci. 82, 273-284.

FAO/WHO, 2011. Evaluation of Certain Contaminants in Food: Seventy-second Report of the Joint FAO/WHO Expert Committee on Food Additives. http:// whqlibdoc.who.int/trs/WHO_TRS_959_eng.pdf.

Fay, L., Gustin, M., 2007. Assessing the influence of different atmospheric and soil mercury concentrations on foliar mercury concentrations in a controlled environment. Water Air Soil Pollut. 181, 373-384.

Feng, X.B., Li, P., Qiu, G.L., Wang, S.F., Li, G.H., Shang, L.H., Meng, B., Jiang, H.M., Bai, W.Y., Li, Z.G., Fu, X.W., 2008. Human exposure to methylmercury through rice intake in mercury mining areas, Guizhou province, China. Environ. Sci. Technol. 42, 326-332.

Feng, X.B., Qiu, G.L., 2008. Mercury pollution in Guizhou, southwestern China - an overview. Sci. Total Environ. 400, 227-237.

Food and Agriculture Organization of the United Nations (FAO), 2006. Rice Is Life. Available at: http://www.fao.org/newsroom/en/news/2006/1000267/index. html.

Gustin, M.S., Lindberg, S., Marsik, F., Casimir, A., Ebinghaus, R., Edwards, G., et al., 1999. Nevada STORMS project: measurement of mercury emissions from naturally enriched surfaces. J. Geophys. Res. 104, 21831-21844.

Holsbeek, L., Das, H.K., Joiris, C.R., 1996. Mercury in human hair and relation to fish consumption in Bangladesh. Sci. Total Environ. 186, 181-188.

Horvat, M., Nolde, N., Fajon, V., Jereb, V., Logar, M., Lojen, S., Jacimovic, R., Falnoga, I., Qu, L.Y., Faganeli, J., Drobne, D., 2003. Total mercury, methylmercury and selenium in mercury polluted areas in the province Guizhou, China. Sci. Total Environ. 304, 231-256.

Issaro, N., Abi-Ghanem, C., Bermond, A., 2009. Fractionation studies of mercury in soils and sediments: a review of the chemical reagents used for mercury extraction. Anal. Chim. Acta 631, 1-12.

Jones, R.D., Jacobson, M.E., Jaffe, R., West-Thomas, J., Arfstrom, C., Alli, A., 1995. Method development and sample processing of water, soil, and tissues for the analysis of total and organic mercury by cold vapor atomic fluorescence spectrometry. Water Air Soil Pollut. 80, 1285-1294.

Krupp, E.M., Mestrot, A., Wielgus, J., Meharg, A.A., Feldmann, J., 2009. The molecular form of mercury in biota: identification of novel mercury peptide complexes in plants. Chem. Commun. 28, 4257-4259.

Li, Y.H., Ji, Y.F., Yang, L.S., Li, S.J., 2007. Effects of mining activity on heavy metals in surface water in lead-zinc deposit area [J]. J. Agro-Environ. Sci. 26 (1), 103-107 (in Chinese).

Li, P., Feng, X.B., Qiu, G.L., Shang, L.H., Wang, S.F., 2008a. Mercury exposure in the population from Wuchuan mercury mining area, Guizhou, China. Sci. Total Environ. 395, 72-79.

Li, G.H., Feng, X.B., Qiu, G.L., Bi, X.Y., Li, Z.G., Zhang, C., Wang, D.Y., Shang, L.H., Guo, Y.N., 2008b. Environmental mercury contamination of an artisanal zinc smelting area in Weining County, Guizhou, China. Environ. Pollut. 154, $21-31$.

Li, L., Wang, F.Y., Meng, B., Lemes, M., Feng, X.B., Jiang, G.B., 2010. Speciation of methylmercury in rice grown from a mercury mining area. Environ. Pollut. 158, 3103-3107.

Li, P., Feng, X.B., Shang, L.H., Qiu, G.L., Meng, B., Zhang, H., Guo, Y.N., Liang, P., 2011. Human co-exposure to mercury vapor and methylmercury in artisanal mercury mining areas, Guizhou, China. Ecotoxicol. Environ. Saf. 74, 473-479.

Lin, Y., Larssen, T., Vogt, R.D., Feng, X.B., 2010. Identification of fractions of mercury in water, soil and sediment from a typical $\mathrm{Hg}$ mining area in Wanshan, Guizhou province, China. Appl. Geochem. 25, 60-68.

Liu, G.L., Cai, Y., Mao, Y.X., Scheidt, D., Kalla, P., Richards, J., Scinto, L., Tachiev, G., Roelant, D., Appleby, C., 2009. Spatial variability in mercury cycling and relevant biogeochemical controls in the Florida everglades. Environ. Sci. Technol. 43, 4361-4366.

Meng, B., Feng, X.B., Qiu, G.L., Cai, Y., Wang, D.Y., Li, P., Shang, L.H., Sommar, J., 2010. Distribution patterns of inorganic mercury and methylmercury in tissues of rice (Oryza sativa L.) plants and possible bioaccumulation pathways. J. Agric. Food Chem. 58, 4951-4958.

Meng, B., Feng, X.B., Qiu, G.L., Liang, P., Li, P., Chen, C.X., Shang, L.H., 2011. The process of methylmercury accumulation in rice (Oryza sativa L.). Environ. Sci. Technol. 45, 2711-2717.

Millán, R., Gamarra, R., Schmid, T. Sierra, M.J., Quejido, A.J., Sánchez, D.M. Cardona, A.I., Fernández, M., Vera, R., 2006. Mercury content in vegetation and soils of the Almadén mining area (Spain). Sci. Total Environ. 368, 79-87. 
Qiu, G.L., Feng, X.B., Wang, S.F., Shang, L.H., 2005. Mercury and methylmercury in riparian soil, sediments, mine-waste calcines, and moss from abandoned $\mathrm{Hg}$ mines in east Guizhou province, southwestern China. Appl. Geochem. 20, 627-638.

Qiu, G.L., Feng, X.B., Wang, S.F., Shang, L.H., 2006. Environmental contamination of mercury from $\mathrm{Hg}$ - mining areas in Wuchuan, northeastern Guizhou, China. Environ. Pollut. 142, 549-558.

Qiu, G.L., Feng, X.B., Li, P., Wang, S.F., Li, G.H., Shang, L.H., Fu, X.W., 2008. Methylmercury accumulation in rice (Oryza sativa L.) grown at abandoned mercury mines in Guizhou, China. J. Agric. Food Chem. 56, 2465-2468.

Qu, L., 2004. A Study on the Prevention and Remedy of Hg-Contamination in Guizhou. Guizhou Press, Guiyang.

Rothenberg, S.E., Feng, X.B., Dong, B., Shang, L.H., Yin, R.S., Yuan, X.B., 2011. Characterization of mercury species in brown and white rice (Oryza sativa L.) grown in water - saving paddies. Environ. Pollut. 159, 1283-1289.

Santos, E.C.O., Camara, V.M., Jesus, I.M., Brabo, E.S., Loureiro, E.C.B., Mascarenhas, A.F.S., Fayal, K.F., Sa, G.C., Sagica, F.E.S., Lima, M.O., Higuchi, H. Silveira, I.M., 2002. A contribution to the establishment of reference values for total mercury levels in hair and fish in Amazonia. Environ. Res. 90, 6-11.

Schwesig, D., Krebs, O., 2003. The role of ground vegetation in the uptake of mercury and methylmercury in a forest ecosystem. Plant Soil 253, 445-455.

Shi, J.B., Liang, L.N., Jiang, G.B., Jin, X.L., 2005. The speciation and bioavailability of mercury in sediments of Haihe River, China. Environ. Int. 31, 357-365.

Shi, J.B., Meng, M., Shao, J.J., Zhang, K.G., Zhang, Q.H., Jiang, G.B., 2013. Spatial distribution of mercury in topsoil from five regions of China. Environ. Sci. Pollut. Res. 20, 1756-1761.

Sierra, M.J., Millán, R., Esteban, E., 2008. Potential use of Solanum melongena in agricultural areas with high mercury background concentrations. Food Chem. Toxicol. 46, 2143-2149.

Sierra, M.J., Millán, R., Cardona, A.I., Schmid, T., 2011. Potential cultivation of Hordeum Vulgare L. in soils with high mercury background concentrations. Int. J. Phytoremediat. 13, 765-778.

Søvik, M., Larssen, T., Vogt, R.D., Wibetoe, G., Feng, X.B., 2011. Potentially harmful elements in rice paddy fields in mercury hot spots in Guizhou, China. Appl Geochem. 26, 167-173.
Stein, E.D., Cohen, Y., Winer, A.M., 1996. Environmental distribution and transformation of mercury compounds. Crit. Rev. Environ. Sci. Technol. 26, 1-43.

USEPA, 1997a. Mercury Study Report to the Congress, EPA 452/R-97-005. USEPA Office of Air Quality Planning and Standards and Office of Research and Development, Washington, DC.

USEPA, 1997b. Mercury Study Report to the Congress, EPA 452/R-97-0003. USEPA Washington, DC.

USEPA, 2001. Method 1630: Methyl Mercury in Water by Distillation, Aqueous Ethylation, Purge and Trap, and CVAFS (EPA-821-R-01-020). US EPA, Washington, DC, pp. 1-41.

Wallschlager, D., Desai, M.V.M., Spengler, M., Wilken, R.D., 1998. Mercury speciation in floodplain soils and sediments along a contaminated river transect. J. Environ. Qual. 27, 1034-1044.

Wang, S.F., Feng, X.B., Qiu, G.L., Wei, Z.Q., Xiao, T.F., 2005. Mercury emission to atmosphere from Lanmuchang $\mathrm{Hg}$ - Tl mining area, Southwestern Guizhou, China. Atmos. Environ. 39, 7459-7473.

Wang, X., Wang, F.H., Chen, B., Sun, F.F., He, W., Wen, D., Liu, X.X., Wang, Q.F., 2012 Comparing the health risk of toxic metals through vegetable consumption between industrial polluted and non-polluted fields in Shaoguan, south China. J. Food Agric. Environ. 10 (2), 943-948.

WHO, 1990. Methylmercury, Environmental Health Criteria. United Nations Environment Programme and the International Labour Organisation, Geneva, p. 101.

WHO, 2007. Exposure to Mercury: a Major Public Health Concern. World Health Organization, Geneva. http://www.who.int/phe/news/Mercury-flyer.pdf.

Zhang, H., Feng, X.B., Larssen, T., Qiu, G.L., Vogt, R.D., 2010a. In inland China, rice rather than fish, is the major pathway for methylmercury exposure. Environ. Health Persp. 118, 1183-1188.

Zhang, H., Feng, X.B., Larssen, T., Shang, L.H., Li, P., 2010b. Bioaccumulation of methylmercury versus inorganic mercury in rice (Oryza sativa L.) grain. Environ. Sci. Technol. 44, 4499-4504.

Zornoza, P., Millán, R., Sierra, M.J., Seco, A., Esteban, E., 2009. Efficiency of the white lupin in the removal of mercury from contaminated soils: soil and hydroponic experiments. J. Environ. Sci. 22 (3), 421-427. 